Portland State University

PDXScholar

\title{
An Analysis of Fraud in the Context of Depreciation Manipulation
}

Sydney G. Jackson

Portland State University

Follow this and additional works at: https://pdxscholar.library.pdx.edu/honorstheses

Part of the Accounting Commons, and the Entrepreneurial and Small Business Operations Commons Let us know how access to this document benefits you.

\section{Recommended Citation}

Jackson, Sydney G., "An Analysis of Fraud in the Context of Depreciation Manipulation" (2020). University Honors Theses. Paper 914.

https://doi.org/10.15760/honors.936

This Thesis is brought to you for free and open access. It has been accepted for inclusion in University Honors Theses by an authorized administrator of PDXScholar. Please contact us if we can make this document more accessible: pdxscholar@pdx.edu. 
An Analysis of Fraud in the Context of Depreciation Manipulation

by

Sydney Jackson

An undergraduate requirement honors thesis submitted in partial

fulfillment of the requirements for the degree of

Bachelor of Science

in

University Honors and Business Honors

in

Accounting

Thesis advisor

Kathleen Rupley

Portland State University 


\section{Introduction}

"Comprehensive, accurate and reliable financial reporting is the bedrock upon which our markets are based because false financial information saps investor confidence and erodes the integrity of the markets."

-Andrew Ceresney, Securities and Exchange Commission (SEC) speech, September 19, 2013

In 2002, Waste Management, an American waste disposal company, was charged by the Securities and Exchange Commission (SEC) for inflating their profits, reporting $\$ 1.7$ billion in fake earnings. The SEC's complaint alleges that Waste Management "fraudulently manipulated the company's financial results to meet predetermined earnings targets" (SEC 2002). When Waste Management's revenues were not meeting targets, the company turned to improper accounting practices to eliminate and defer current period expenses to inflate earning. Listed in the numerous complaints, the SEC charged Waste Management for "avoiding depreciation expenses on their garbage trucks by both assigning unsupported and inflated salvage values and extending their useful lives" and "assigned arbitrary salvage values to other assets that previously had no salvage value" (SEC 2002). In a further investigation, the SEC determined that the fraudulent activity centralized at corporate headquarters. With a lack of organizational control and balances, the executive management team artificially reduced expenses and inflated earnings by using "top level adjustments" to conform the company's actual results to the predetermined earnings targets.

Accounting scandals, such as Waste Management's shatter investor confidence, destroy employee retirement plans, and negatively impact the U.S. economy as a whole. A study by Karpoff, Lee and Martin finds that companies lose an average of 38\% of their market share when disclosing financial statement misrepresentations (Karpoff, et al., 2008). In response to the Enron and WorldCom financial scandals, Congress passed the Sarbanes-Oxley Act of 2002 to 
better protect investors (SOX; US Congress 2002). The Sarbanes-Oxley Act, often referred to as SOX, has the purpose to ensure the accuracy and reliability in corporate financial statements so that investors have more confidence and protection. Subsection 404 of SOX focuses on the internal control and management responsibilities of financial reporting. SOX 404 requires companies to perform internal control tests, holds management responsible for the accuracy of financial statements, and requires large public companies to have their independent auditors attest to the disclosure assessment created by the company. Although SOX has been in effect for almost two decades, fraud continues to occur.

Hertz Global Holdings Inc. and it's wholly-owned subsidiary The Hertz Corp. is the second largest American car and equipment rental company that operates in 150 countries. On February 1, 2019, Hertz Global Holdings Inc. and The Hertz Corp. paid a \$16 million fraud settlement, brought on by the SEC, charging for the filing of inaccurate financial statements and disclosures. The Securities and Exchange Commission, File No. 3-18965 states:

“According to the SEC's order, from February 2012 through March 2014, Hertz's public filings materially misstated pre-tax income because of accounting errors made in a number of business units over multiple reporting periods. In July 2015, Hertz restated its financial results for prior periods, identifying $\$ 235$ million in previously reported pre-tax income based on treatment of items that was not consistent with generally accepted accounting principles (GAAP). The SEC's order finds that the inaccurate reporting occurred in a pressured corporate environment that placed improper emphasis on meeting internal budgets, business plans, and earnings estimates. " 
In regards to deprecation, the SEC order found that during 2013 Hertz "failed to adequately disclose a decision to extend the planned holding periods for substantial portions of its U.S. rental car fleet, which beneficially impacted the company's financial statements in the short term by lowering the depreciation expense for current quarters, but also carried long-term risks including that older cars were likely to require increased maintenance costs, and could injure Hertz's premium brand.” During this 2011 to 2013 period, PricewaterhouseCoopers had given Hertz clean audit reports.

In a press release given by Hertz on July 16, 2015, Hertz Global Holdings Inc announced that they "filed its Annual Report on Form 10-K for the fiscal year ending December 31, 2014, which includes the restated results for 2012 and 2013 as well as selected unaudited restated financial information for 2011.” In July 2015, Hertz restated its financial results for prior periods, identifying \$235 million in previously reported pre-tax income based on treatment of items that was not consistent with generally accepted accounting principles (GAAP) (Administrative Proceedings, 2019). In the select 2011 statements, a restatement of at least $\$ 46.3$ million was made to correct accounting errors (HGH 8-K 2014). The 8-K said that "During the preparation of the First Quarter 10-Q, errors were identified relating to Hertz's conclusions regarding the capitalization and timing of depreciation for certain non-fleet assets, allowances for doubtful accounts in Brazil, as well as other items.” Upon this, Hertz said, the company “continued its review and recently identified additional errors related to allowances for uncollectible amounts with respect to renter obligations for damaged vehicles and restoration obligations at the end of facility leases." Hertz Global Holding's Inc's internal audit committee conducted a thorough review of the financial records from 2011 to 2013 . However, warned in 
the 8-K, "this review may require Hertz to make further adjustments to the 2012 and 2013 financial statements."

By having a clear understanding of the internal and external forces that drive the motivation of fraud, accountants and businesses are better able to prep and set proper internal controls. As proper internal controls prevent fraud, this thesis will explore catching fraud through financial implications, by focusing specifically on the fraud committed through depreciation. By conducting a financial analysis on Hertz Global Holding, this thesis seeks to pinpoint when a company or financial statement users should be wary of fraud through deprecation. Using the company's 10-K's and 8-K's, I plan to look at the depreciation percentages of revenues, changes in holding period, and net income trends, to give an idea of when an auditor, investor, or someone looking at the financial statements should be weary of fraud, specifically in depreciation. In this paper, I will examine prior research related to fraud motivation and consequences in Section II. In Section III. I will further examine whether the Hertz Corporation fraud could have been detected and Section IV provides a conclusion.

\section{Prior Research on Fraud}

In the study, "The Causes and Consequences of Accounting Fraud," Gerety and Lehn investigate potential causes of fraud based on the perspective that accounting fraud is governed by rational choice (Gerety and Lehn, 1999). The authors broadly categorize the choice of committing fraud to result from external or internal forces, which is now seen as a common categorization throughout the accounting discourse community. In 1950, sociologist and criminologist, Donald Cressey studied why people commit fraud and created a theory to explain why a violator would commit fraudulent behavior within their occupation. This theory, known 
as the Fraud Triangle consists of three factors - opportunity, pressure, and rationalization (Cressey, 1971).

Although Cressey's Fraud Triangle was supported and used by audit regulators such as the Accounting Standards Board (ASB) and International Auditing and Assurance Standards Board (IAASB), critics such as Kassem and Higson argue that "it cannot help alone in explaining fraud because two factors cannot be observed (rationalization and pressure), and other important factors, like capabilities of the fraudsters, are ignored" (Kassem and Higson, 2012). In their study titled, “The New Fraud Triangle Model" Kassem and Higson consider three fraud models: Cressey’s Fraud Triangle, Vona's Classifications of Pressure/Motive, and Wolfe and Hermanson's Fraud Diamond Model. Leonard Vona (2008) created a model, the Classifications of Pressure/Motive, to show that motives to commit fraud are often due to personal pressures, corporate employment pressures, and external pressures. The Wolfe and Hermanson (2004) Fraud Diamond model displays their perception of what motivates fraud: incentive, opportunity, rationalization, and capability. Kassem and Higson agree that it is important to use all of the fraud models to better understand why fraud occurs. Thus, they suggest the New Fraud Triangle Model as an extension of Cressey's Fraud Triangle to include four factors: motivation, opportunity, integrity, and fraudster's capabilities (Kassem and Higson, 2012). While Cressey's Fraud Triangle and Kassem and Higson's New Fraud Triangle focus on internal factors that drive people to commit fraud, it is also important to consider the external factors that can drive individuals to commit fraudulent behavior.

In the article, "Understanding the Causes and Effects of Top Management Fraud," Zahra, Priem, and Rasheed (2007) examine different types of fraud committed by top managers and link them to various classes of white-collar crime. White-collar crimes are classified by strong 
financial motivations, involvement of individuals who are considered respectable members of society and have the absence of physical violence. Top management fraud can take many forms including embezzlement, insider trading, self-dealing, lying about facts, failure to disclose facts, corruption, cover-up, and misrepresentation of financial statements (Zahra, et al., 2007). Top management fraud has wide reaching effects on shareholders, employees, the community, and society at large. The study focuses on the many external forces such as societal, industry, and organizational factors that pressure top level managers to commit fraud. From an organizational level, most fraud pressures are found in the board composition, senior leadership, and the organizational culture. From an industry-level perspective, the study finds many factors that influence top management fraud. These consist of industry cultures, norms, and histories; industry level investment horizons, payback periods, and financial returns; industry concentration; environmental hostility; environmental dynamites; and environmental heterogeneity (Zahra, et al., 2007). Similar to Cressey's internal factors that drive people to commit fraud, this study first looks at characteristics that can contribute to an individual committing fraud such as age, experience, gender, self-control, and education. While considering these individual factors, the study finds that top management level fraud mainly stems from societal-level pressures, based on the underlying idea of cultural deviance. These societal-level pressures are created through an organization's culture, norms, histories, concentrations, and environmental dynamics - in which organizational and industry-level pressures have a large role in creating.

Just as Zahra et al. have looked at the importance of industry-level pressures, Crutchley, Jensen, and Marshall (2007) attest to these industry-level forces and more in their study titled, "Climate for Scandal: Corporate Environments that Contribute to Accounting Fraud." In this 
study, they explore how corporate governance, earnings quality, growth rate, dividend policy, and compensation work together to create an environment conducive to fraud. Upon review of each of these components, they come to the conclusion that "the corporate environment most likely to lead to an accounting scandal is characterized by rapid growth, high earnings smoothing, fewer outside directors on the audit committee, and outside directors that seem overcommitted" (Crutchley, et al., 2007).

It is important to understand what motivates people to commit fraud to better assess risk and to implement appropriate preventive and detective measures (Wells, 2001). Through a review of literature, the motivations of fraudulent behavior is broadly categorized by internal and external forces. External forces from a societal, industry, and organizational level as well as non-sharable financial problems shape a company and often play a large role on how employees view their company. The internal forces that drive people to commit fraud often have to do with how an employee views a company, the level of pressure, opportunity, rationalization, or certain personality characteristics.

Depreciation is not a real cash expense, but instead a transaction that allows accountants to reduce the value of tangible assets over time. As the asset is used, a calculated depreciation amount is expensed every year until the entire value of the asset is written off. As the assets are written off over time, the amount is expensed on the income statement, and the new asset value is recorded at new book value on the balance sheet. The calculation for depreciation expense is used when determining adjusted net income for tax purposes, "the net effect is lower asset values and a lower net income. Since depreciation expense affects net income and the amount paid to the IRS for taxes on net income, depreciation fraud is not unusual to find, particular if the company is under financial distress" (Collins, 2019). 
The three most commonly used depreciation methods are Straight-line, Double Declining Balance (DDB), and Sum-of-the-years digits (SOYD). The most commonly used method of depreciation is the straight-line method, where the cost of depreciation is spread evenly over the life of the asset. DDB and SOYD are considered more aggressive forms of depreciation. For example, "a company using DDB will report higher depreciation expense than one using straight-line. For analytical purposes, since depreciation is a non-cash expense, it is subtracted from operating expenses but added back to cash flows from operations. A company using DDB will show lower operating expenses and better cash flow, which may not be truly representative" (Saint-Leger, 2017). The choice of which depreciation methods is based on management's discretion. When depreciating assets, a company is making an estimation of the asset's useful life. "Depending on which depreciation method is used, a company can be too aggressive in writing off assets or its estimate of an asset's useful life may be overexaggerated" (Saint-Leger, 2017).

Since deprecation is a non-cash transaction and the depreciation methods is based on management's discretion companies are able to commit white collared fraud by misrepresenting assets or claiming longer holding period. Since the depreciation expense directly affects assets on the balance sheet and net income, this affects stockholders' equity, as a higher net income increases equity through retained earnings. Because the deprecation calculation is a non-cash representation, companies can use this to skew their market-to market-representation. This refers to the valuation of the asset's current market price rather than its book value. Where a distortion can occur is if the asset's depreciation is based on book value rather than actual market value (Saint-Leger, 2017). 
On top of property, plant, and equipment internal controls, companies should take precautions and auditors should be wary of fraud committed in the depreciation calculation. As an auditor, it would be useful to compare a company's depreciation method to other companies within the industry. If a company were to change their depreciation method, it would be important to consider their reasoning as well as conduct an analysis by subtracting the more conservative depreciation method from operating expenses in order to get a clear picture of the company's financial health and peer comparison. Similarly, by valuing a company's assets based on current market prices rather than book value will give a clear and comparable picture. With professional skepticism, an auditor should identify how the deprecation expense has changed during that expected period. "If depreciation expense is going up, it is a sign the company has purchased additional assets and is writing off more of assets over time. If depreciation expense decreased significantly, it is a sign that the company has fewer assets on the books" (Collins, 2019). In the book, "Fraud Examination," Albrecht et al. (2009) discusses the overstatement of fixed assets. They determine that overstated fixed assets generally arise from one of the following three ways:

1. Inflated amounts are recorded in non-arm's length purchases.

2. Assets are not written down to their appropriate values because insufficient depreciation is recorded, they are obsolete, or their values are otherwise impaired.

3. Assets are fictitiously recorded in financial statement accounts.

The authors then discuss four types of analysis that could be performed to determine if the fixed assets were overstated:

The first two ratios provide evidence about whether fixed asset balances are reasonable relative to other asset balances- 
- Total fixed assets/Total assets

- Individual fixed asset account balances/Total fixed assets

The third ratio identifies the relationship between debt and fixed assets-

- Total fixed assets/Long-term debt

The final two ratios provide a deeper analysis of depreciable assets per category-

- Depreciation expense for various categories of assets/Assets being depreciated

- Accumulated depreciation/Depreciable assets (per asset category) (Pg. 469)

\section{Examination of the Hertz Fraud}

In January 2020, Wasiu Raji conducted a critical review of the accounting errors made by Hertz Global Holdings, Inc. In this study, Raji explores the avoidable series of accounting errors of HGH and discusses that if due diligence had been followed and ethical accounting practice had been employed, the company would not have found themselves in this situation, and what the company should do in the future to avoid such errors (Raji, 2020).

In his study, Raji deduces that the accounting errors were caused by:

- Misstated material information in the financial statements

- Two general ways of manipulating financial statements are either by exaggerating the current period earnings on the income statement through inflation of the company's revenue gaining artificially or by deflating the current period expenses or doing both. By doing so, the manipulation makes the financial condition of the company look better than it actually is in order to meet predetermined expectations set by management of the company (Adkins, 2019).

- Use of inappropriate \& consistent methodologies 
- A pressured corporate environment where inappropriate emphasis on meeting internal budgets, business plans and earnings estimates are employed for a predetermined favorable financial impact provide an environment conducive for fraud. In such situations, managers would often rationalize fraudulent and other unethical behavior by convincing themselves that they are acting in the best interest of the company for which they work for (Morgan \& Burnside, 2014). It is likely that Hertz employees were under similar pressure and therefore estimated am understated allowance estimated an allowance for uncollectible amounts as an offset to what was recorded as potential recoveries, however, for years, the company's allowance-related expenses were understated and its income was inflated because the company relied on inappropriate estimation methodologies that resulted in inadequate allowances and write-offs (Cohn, 2019).

- Hidden or concealed Financial Information

- In the 2013 financial statement of the company, the company failed to adequately disclose the decision to extend the planned holding periods for substantial portions of its US rental car fleet (Cohn, 2019). However, in 2013 the company decided to extend the holding periods of a significant part of its rental car fleet, this decision and its impact was concealed to the investors (Bloomenthal, 2019).

○ The company lowered its 2013 earnings guidance to $\$ 1.68-\$ 1.78$ per share wrongly and deliberately reaffirm that guidance, despite the fact that a more current internal analysis projected earnings share of only $\$ 1.65$ (Administrative Proceeding, 2019). 
- This can potentially influence the analyst stock rating which may affect the decision of an investor to buy, hold, or sell in the security (Raji, 2020).

Raji then proposes alternatives to Hertz in order to not fall into this kind of situation again:

- Employment of ethical accounting practice as part of hurts company culture

- Disclosure of all relevant information of their financial statements

- Employ the use of appropriate accounting methodology and be consistent with the selected methodology

- Employ the service of external accounting firm

There are many benefits that can come out of these proposed alternatives. Hertz Global Holdings paid penalties of $\$ 16$ million although neither confirming nor denying the allegations. On top of the loss of money, there will be a loss of public perception that may never be recovered. Hertz will no doubt be increasing internal controls to mitigate risk of future fraud and misstatement. In addition to these controls, Hertz should be conducting a year over year analysis to compare drastic changes and also analysis of depreciation percentages compared to net income.

The company allegedly overstated GAAP net income by $\$ 87$ million over 2011 to 2013. The restatement of these earnings statements would reduce net income to $18 \%, 14 \%$ and $6 \%$ for its 2011, 2012 and 2013 fiscal years, in dollar terms \$32 million, \$35 million and \$20 million (Heller, 2014). In Figure 2, series 1 shows the net income attributable to Hertz Global Holdings from 2009 to 2019. Series 2 depicts the restated financials over the years 2011 and 2013. 


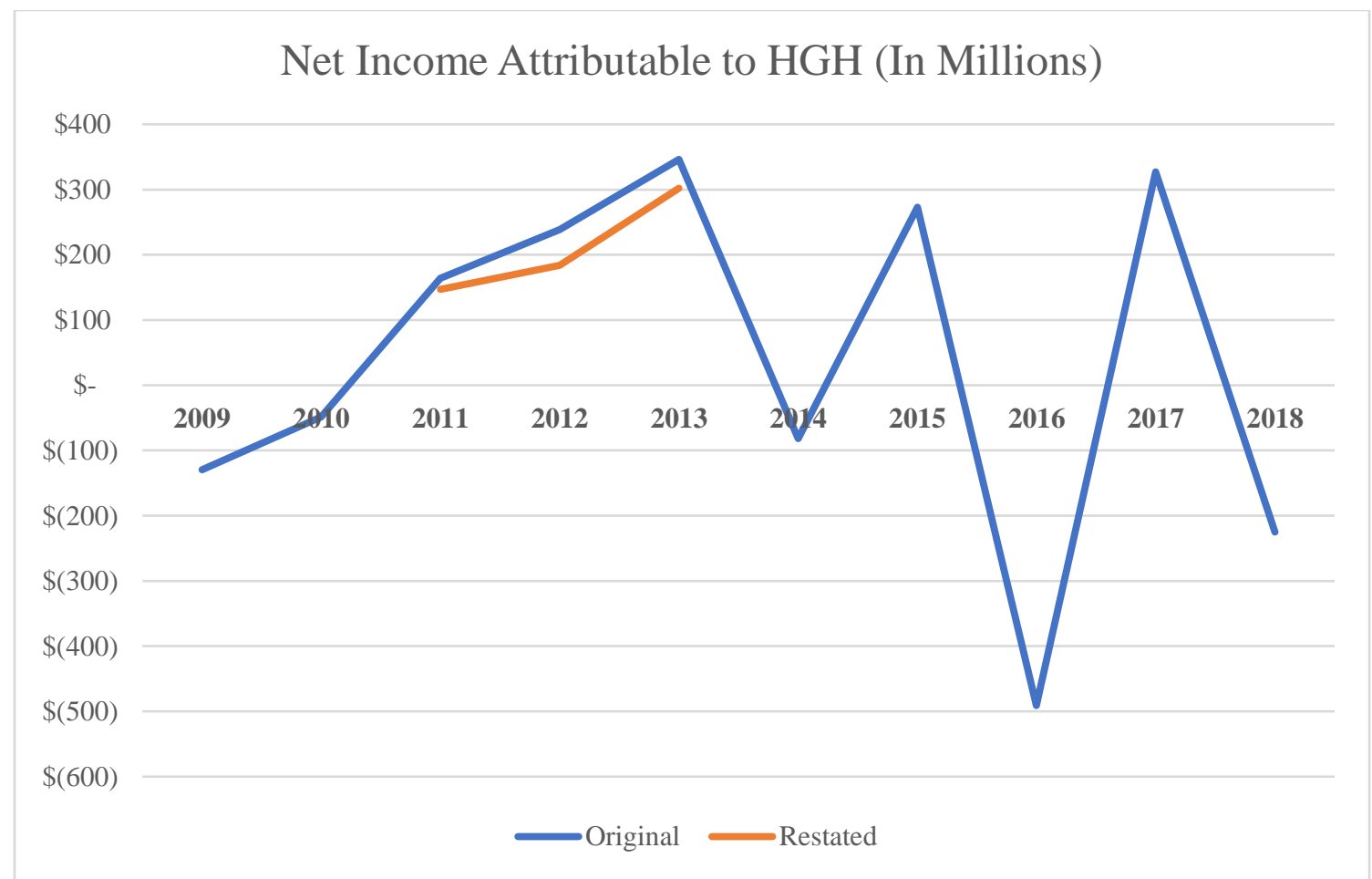

\section{Figure 1 (HGH 10-K)}

As a rental car company, a large part of Hertz Global Holding's business is depreciating their service vehicles and equipment to correctly expense and amortize them over time. Hertz depreciates their property and equipment using the straight- line method over the estimated useful lives of each asset. This depreciation method is commonly used for rental car and equipment companies. Over the years, the set useful lives for revenue earning equipment has varied but have been disclosed within the 10-K's.

The holding period of an asset or investment is important to understand in order that ultimately affect net income, thus overall taxes. "Calculating how long you've held an asset is a fundamental component of the tax treatment of capital gains and losses, because the Internal Revenue Code distinguishes between short-term and long-term gains and losses. Long-term gains on most assets are taxed at lower rates than are short-term gains or ordinary income. Under the current law, an asset has a long-term holding period if it has been held, or is deemed to have 
been held, for more than one year" (Lewis, 2008). Planned holding periods is part of Hertz's formula used to depreciate its care rental assets. This not only impacts their depreciation expense, but could also impact other aspects of the business, such as maintenance costs. "In 2013, Hertz decided to extend the holding periods of a significant part of its car rental fleet in the U.S. 'That decision, and its impact on aspects of Hertz's business, were not adequately disclosed to investors,' said the SEC. 'Also in 2013, after having already revised its earnings guidance downward, Hertz reaffirmed the revised guidance publicly in November 2013 despite certain internal analysis indicating that the revised guidance had been based in part on inaccurate information and that certain recent internal estimates fell below the low end of that guidance range"” (Cohn, 2019).

As established in the 2011 10-K, the provisions for depreciation and amortization are computed on a straight-line basis over the estimated useful lives of the respective assets, or in the case of revenue earning equipment over the estimated holding period, as follows:

\section{Revenue Earning Equipment:}

Cars

Other equipment

Buildings

Furniture and fixtures

Centralized internal use software

Service cars and service equipment

Other intangible assets

Leasehold improvements
4 to 26 months

24 to 108 months

3 to 50 years

1 to 15 years

1 to 15 years

1 to 13 years

3 to 20 years

The shorter of their economic lives or the lease term.

It is established that Hertz records their depreciation on a straight-line basis over the estimated holding period. On a quarterly basis, management sets depreciation rates based on their ongoing assessment of present and estimated future market conditions, their effect on residual values at the time of the disposal and estimated holding periods. These key factors are 
considered when estimating future residual values and assessing depreciation rates. As a result of this ongoing assessment, they make periodic adjustments to depreciation rates of revenue earning equipment in response to changed market conditions. Upon disposal of revenue earning equipment, depreciation expense is adjusted for the difference between the net proceeds received and the remaining net book value (HGH 10-K).

Revenue earning equipment less its accumulated depreciation is calculated as part of the balance sheet total assets. Figure 2 shows originally stated total assets in millions over 2011 to 2015.

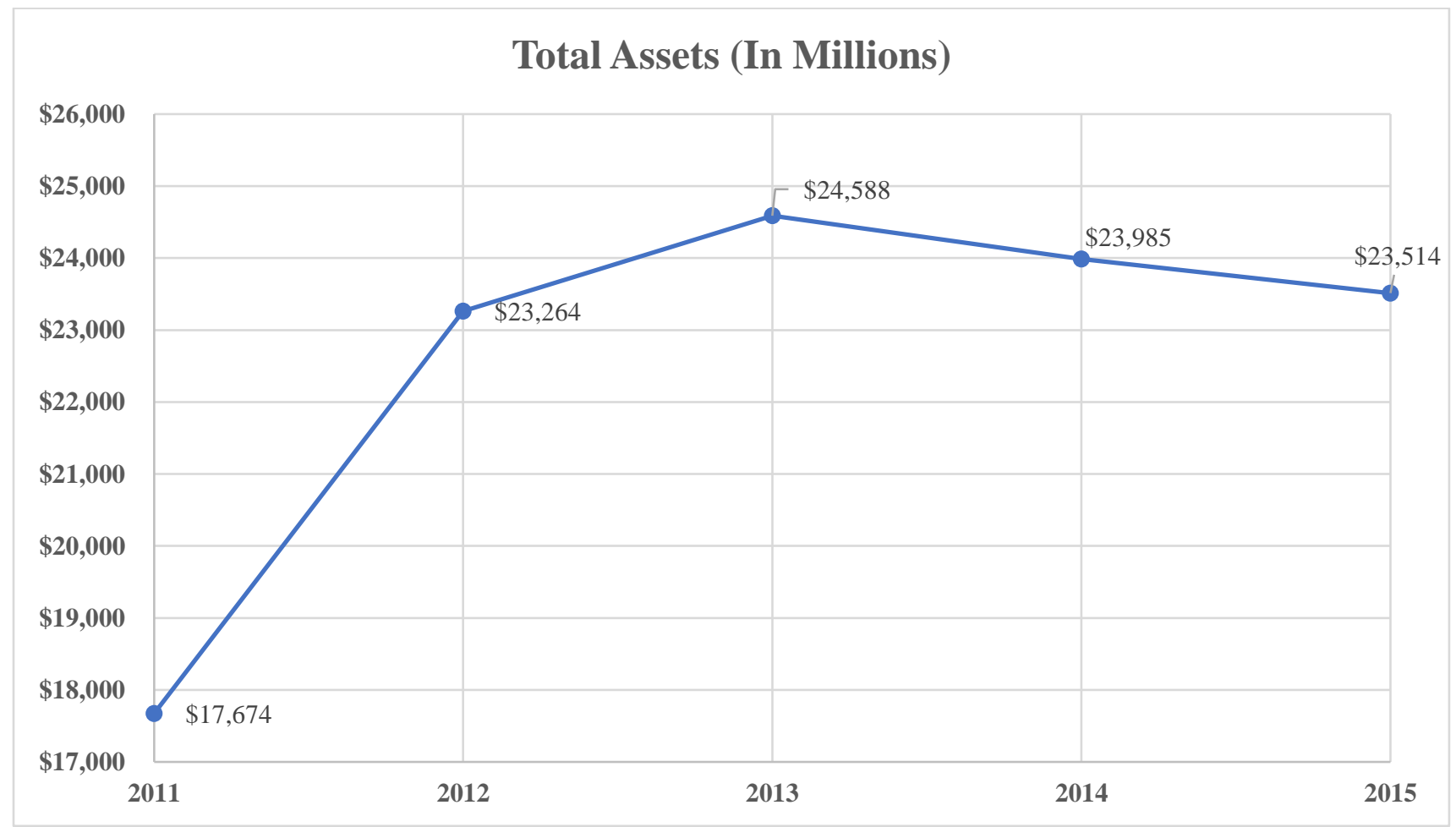

Figure 2 (HGH 10-K)

Noting the substantial increase in total assets from 2011 to 2013, Figure 3 analyzes net revenue earning vehicles, as a depreciable asset of part of the total asset category. Figure 3 shows this over the period of 2011 to 2015, displaying a similar trend between Figure 2, as more revenue is made per vehicles and in total assets. 


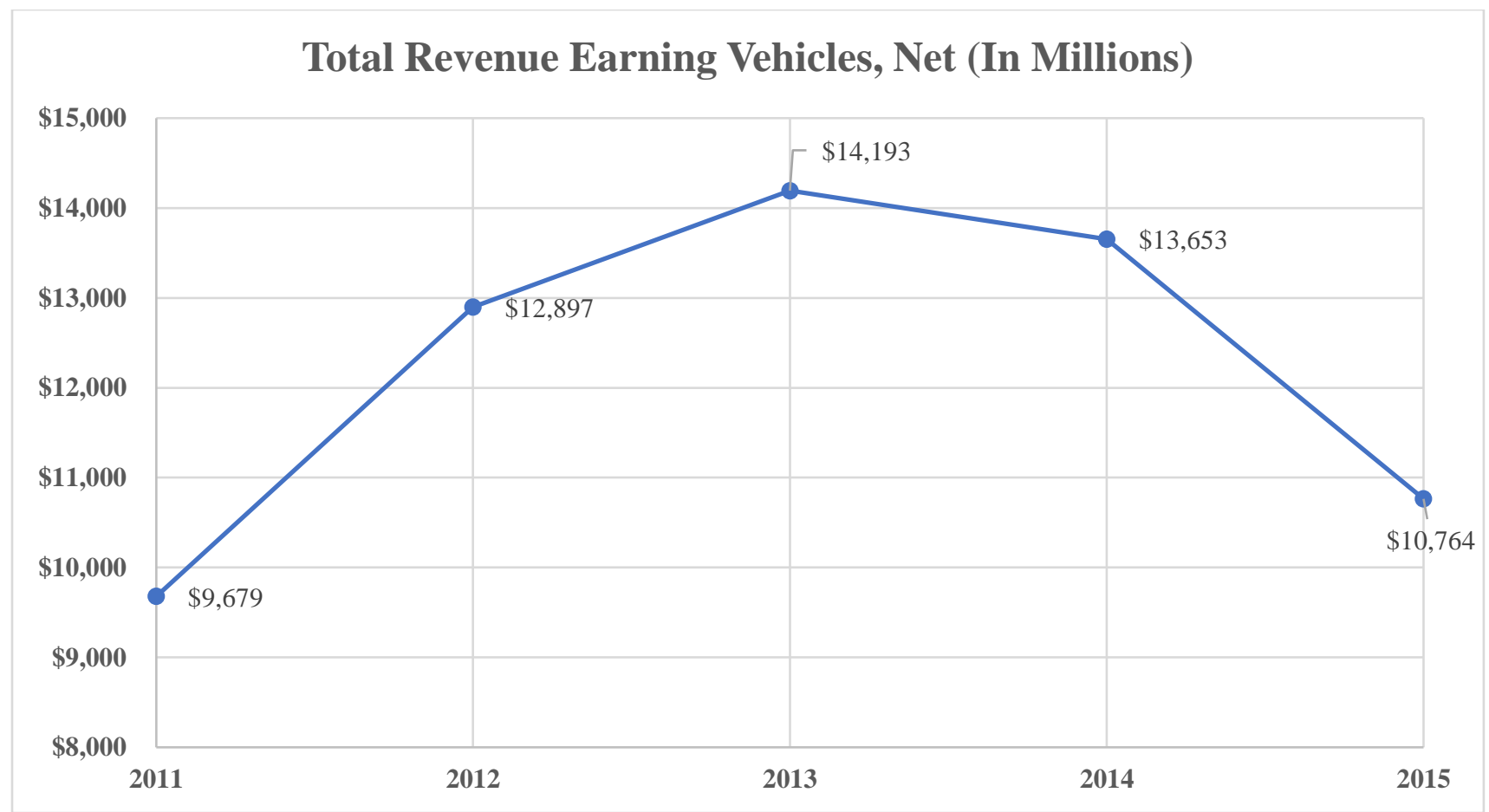

Figure 3 (HGH 10-K)

When Hertz acquired its revenue earning vehicles, the company estimates the period that the asset will be held, basing this information on historical measures of the amount of rental activity and the targeted age of equipment at the time of its disposal (HGH 10-K). 


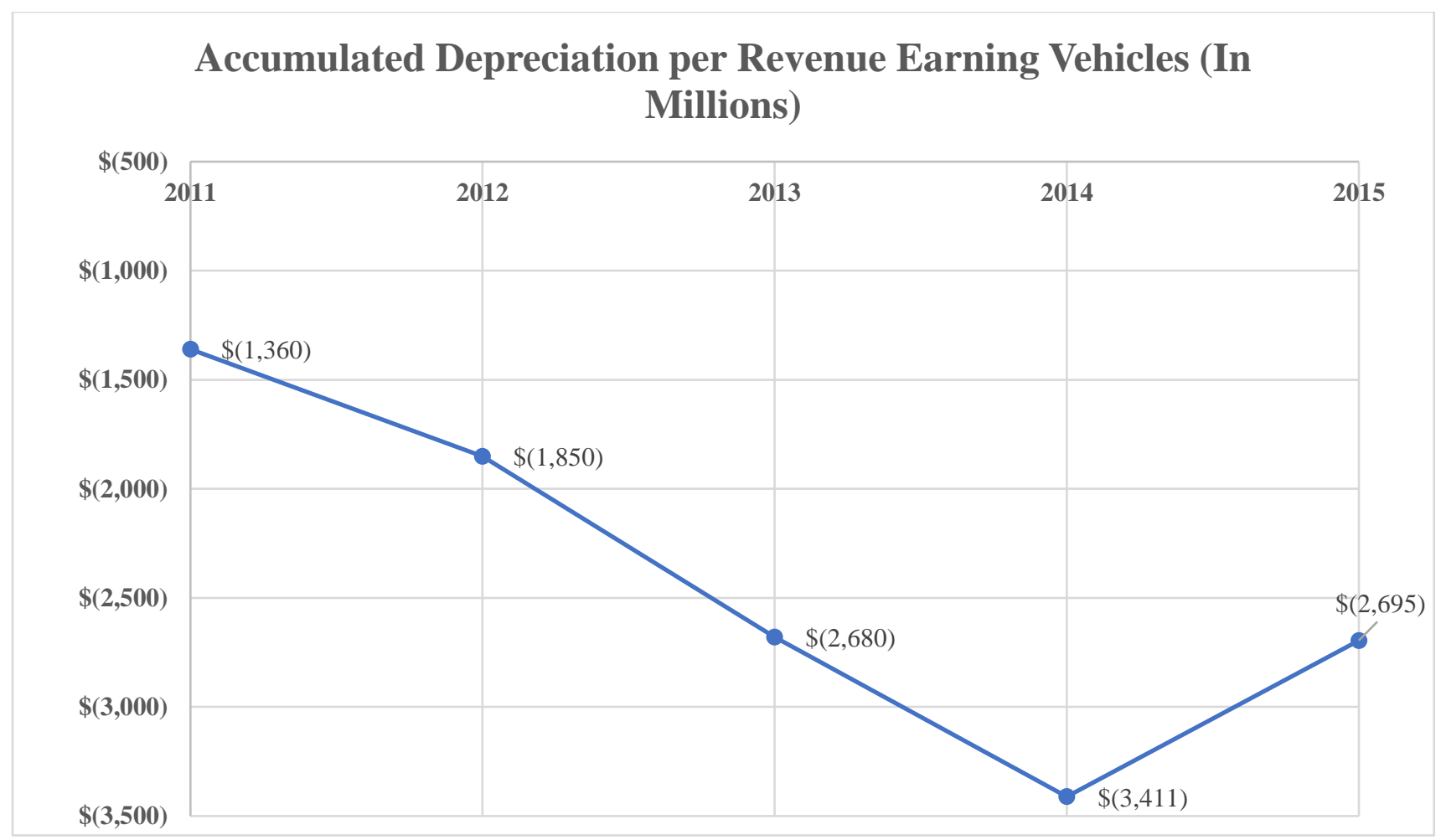

Figure 4 (HGH 10-K)

In Figure 4, depreciation expense increasing from 2011 to 2014. As the expense increases, this is sign that a company is purchasing and writing off more expenses over time, which is confirmed in Figure 3. As a rental car company, the revenue earning service vehicles generate a large portion of Hertz revenues. As seen in Figure 2 and 3 revenue earning vehicles and total assets are increasing. With this increase, Hertz should expect an increase in accumulated depreciation expenses, as correlated in Figure 4. 


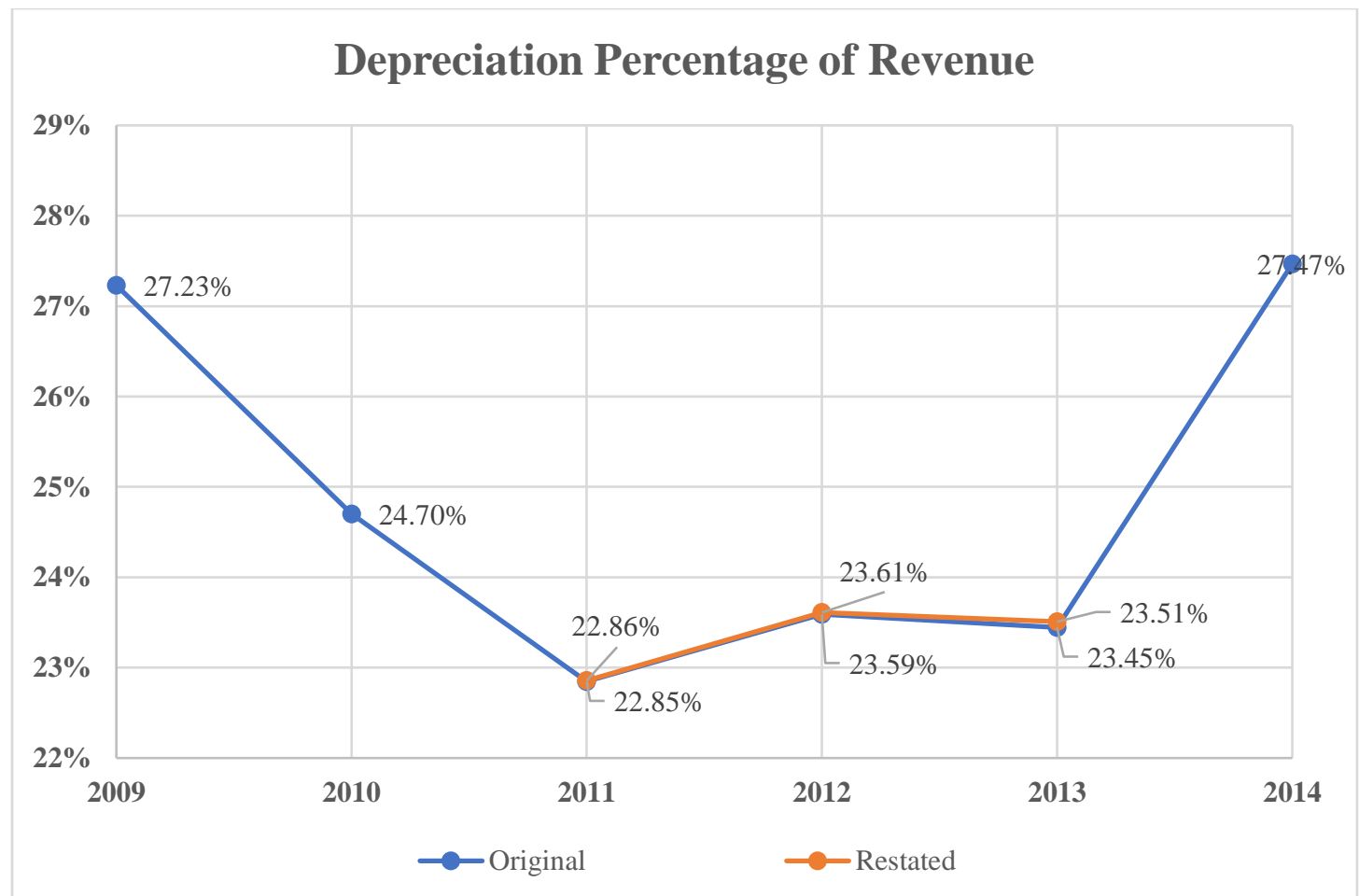

Figure 5 (HGH 10-K)

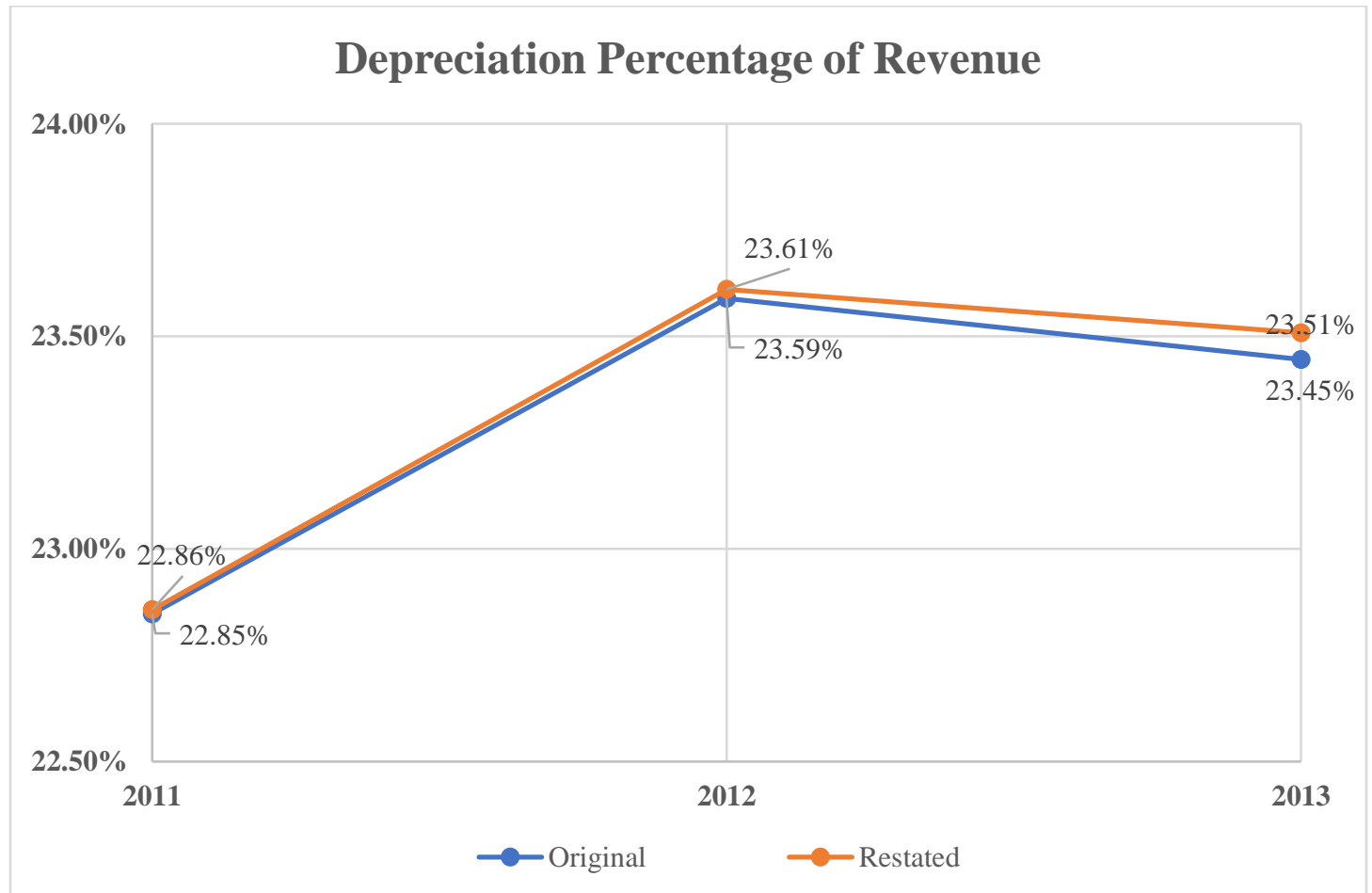

Figure 6 (HGH 10-K) 
For a company with a large focus on their depreciable assets, there should be a direct correlation between revenues and depreciation. Figure 5 displays an analysis of HGH's depreciation percentage of revenues from 2009 to 2014 and Figure 6 shows this over 2011 to 2013 restated period. The restated depreciation percentage of revenue are higher than the originally stated percentage. As the percentages are not significantly different, more components would need to be analyzed in order to prove that there is fraud in deprecation.

\section{Conclusion}

The Waste Management accounting scandal was the largest restatement in corporate history reporting \$1.7 billion in fake earnings. Similar to Waste Management, Hertz Global Holdings, Inc. allegedly manipulated their financials in order to meet predetermine targets. After the fact, both investigations showed that the fraud had been committed through misstating depreciation expenses and that the pressures within the corporate environment had an effect on this process.

It was found that the corporate environment put an inappropriate emphasis on meeting budgets, plans, and estimates, causing inappropriate methodologies to occur. Companies should have an understanding of the internal external forces that drive the motivation of fraud, so that accountants and businesses can both focus on and implement proper preventive and detective measures within their organization.

This study has its short comings. PricewaterhouseCoopers had given Hertz clean audit reports from 2011 to 2013. Without access to this company information, one analysis of a company after the fact that its financials have been restated may not prove how to catch depreciation fraud. However, this study can be built upon and shed light onto the importance of 
a year over year analysis and proper and enforced internal controls regarding the components and reporting of depreciation. Since depreciation is not a real cash expense, the method is based on management discretion, and has multiple moving components to calculate it, companies should be extra cautious and wary of fraudulent behavior in this area. With a better understanding of this, companies are able to set proper internal controls and detective measures regarding each component of depreciation to ultimately work towards the prevention of misstated financials to protect companies, investors, and the economy. 


\section{Bibliography}

Adkins, T. (2019). Financial Statement Manipulation. Retrieved on December 24th, 2019 from: http://www.investopedia.com/articles/fundamental-analysis/financial-statementmanipulation.asp

Administrative Proceeding (2019). SEC Charges Hertz with Inaccurate Financial Reporting and Other Failures. File No. 3-18965. Retrieved from: https://www.sec.gov/enforce/3310601-s

Albrecht, W. S. (2009). Fraud examination. Cengage Learning South-Western

Bloomenthal, A. (2019). Guidance. Retrieved on January 4th, 2020 from: http://www.investopedia.com/terms/g/guidance.asp

Ceresney, A. (2013). Financial reporting and accounting fraud. Talk presented at the American Law Institute Continuing Legal Education. Washington, D.C.

Cohn, M. (2019). SEC penalizes Hertz \$16M for accounting violations. Retrieved on December 24th, 2019 from: https:/www.accountingtoday.com/news/sec-penalizes-hertz-16m-foraccounting-violations

Collins, J. (2019, January 10). How to Detect Depreciation Fraud. Retrieved from https://pocketsense.com/detect-depreciation-fraud-7576472.html

Cressey, D. R. (1953). Other peoples' money: A study in the social psychology of embezzlement. Glenco: Free Press.

Crutchley, C. E., Jensen, M. R. and Marshall, B. B. (2007), Climate for scandal: corporate environments that contribute to accounting fraud. Financial Review, 42: 53-73. doi:10.1111/j.1540-6288.2007.00161.x

Gerety, M. \& Lehn, K. (1999). The causes and consequences of accounting fraud. Managerial and Decision Economics, 18 (7-8). 587-589. Retrieved from www.jstor.org/stable/3108221.

Heller, M. (2014). Hertz Board Finds \$87M in Accounting Errors. Retrieved on December 4th, 2019 from: https://www.cfo.com/management-accounting/2014/11/hertz-board-finds$87 \mathrm{~m}$-accounting-errors/

Hertz Completes Financial Restatement; Provides 2015 Business Outlook. (2015, July 16). Retrieved from http://ir.hertz.com/2015-07-16-Hertz-Completes-Financial-RestatementProvides-2015-Business-Outlook

Hertz Global Holdings Inc. (2008-2018). Form 10-K 2008-2018. Retrieved from SEC EDGAR website http://www.sec.gov/edgar.shtml

Hertz Global Holdings Inc. (2014). Form 8-K 2014. Retrieved from SEC EDGAR website http://www.sec.gov/edgar.shtml

Karpoff, J., Lee, D., \& Martin, G. (2008). The Cost to Firms of Cooking the Books. The Journal of Financial and Quantitative Analysis, 43(3), 581-611. Retrieved June 9, 2020, from www.jstor.org/stable/27647364

Kassem, R. and Higson, A.W. (2012). The new fraud triangle model. Journal of Emerging Trends in Economics and Management Sciences, 3 (3), 191-195

Lewis, Roy. "How to Calculate a Holding Period." The Motley Fool, The Motley Fool, 7 Apr. 2008, www.fool.com/taxes/how-to-calculate-a-holding-period.aspx.

McCann, D. (2014). Did Hertz CFO Leave Because of Accounting Flubs? Retrieved on December 3rd, 2019 from: https://www.cfo.com/accounting-tax/2014/06/hertz-cfo-leaveaccounting-flubs/ 
Raji, Wasiu. (2020). A critical Review of the Accounting Errors by Hertz Global Holdings, Inc.. 10.13140/RG.2.2.17004.51846.

Reuters (2019). Hertz to restate results for 2011-2013 shares skid. Retrieved on December 3rd, 2019 from: https://www.cnbc.com/2014/06/06/hertz-to-restate-results-for-the-past-threeyears-to-correct-accounting- errors.html

Saint-Leger, Randolf (2017). Problems with Depreciation. Retrieved

from https://pocketsense.com/detect-depreciation-fraud-7576472.html

SEC (2002) Retrieved from http://www.sec.gov/news/headlines/wastemgmt6.htm

US Congress. (2002). Sarbanes-Oxley Act of 2002. H.R. 3763.

Wells, J. (2001). Why employees commit fraud. Journal of Accountancy., 191(2), 89. Retrieved from https://www.journalofaccountancy.com/

Vona, L. W. (2008). Fraud risk assessment: Building a fraud audit program. Hoboken New Jersey: John Wiley and Sons, pp.1-250

Wolfe, D. T. and Hermanson, D. R. (2004). "The fraud diamond: Considering the four elements of fraud". The CPA Journal, December, pp.1-5

Zahra, S.A., Priem, R.L., \& Rasheed, Abdul A. (2007). Understanding the causes and effects of top management fraud. Organizational Dynamics, 36 (2). 122-139. Retrieved from https://doi.org/10.1016/j.orgdyn.2007.03.002. 